\title{
Integration of ICT in Education in a Secondary School in Kenya: A Case Study
}

\author{
Florence Kanorio Kisirkoi \\ Lecturer in Maasai Mara University, Kenya
}

\begin{abstract}
Amidst reports that there was very little integration of Communication Information Technology (ICT) in curriculum delivery in many secondary schools in Kenya, it was reported that one secondary school was using ICT in instruction and practicing learner centered instructional approaches and there was improved learning outcomes. The school's mean score in the Kenya Certificate of Secondary Education had improved from 6.2 to 8.4 between 2007 and 2013. This study teacher computer literacy levels, motivation for integration, perceived reason for the intervention and the impact on teaching and learning. A case study was conducted and observation and interview schedules were used to collect data. The study population was the 535 students and the 28 teachers in the school. Simple random sampling was used to sample 30 students and 18 teachers. It was established that the students and teachers were computer literate and were able to manage computer applications for teaching and learning. The Learning process was found to be practical with learner interactions and activities based learning. The motivation was desire to teach better coupled with visionary, supportive school leadership. The school was using ICT as teaching learning tool and there was improvement of learning environment and outcomes. Many schools ought to emulate the school.
\end{abstract}

\section{Introduction}

Quality education is a key concern as a means of preparing learners for the knowledge economy. ICT integration is described as the means of using any ICT tool such as Internet, e-learning technologies and CD ROMs to assist teaching and learning [19]. Use of Information Communication Technologies (ICTs) in education has been reported to result in many learning benefits though it is quite demanding [1]. ICTs in this study include the computer, the internet and CD ROMs. Enough preparation must be put in place for ICT integration in education to succeed. It requires keen planning, effective teacher preparation and sustained regular teacher professional support and visionary leadership that recognizes the need to prepare the learners to live and work in the technological world of the $21 \mathrm{st}$ century. It also requires a teachers' attitude that is adaptive to change and appreciation of the fact that in many ways modern technology enriches pedagogies. To achieve that, teachers might also require training and sustained professional development.

Use of ICTs also demands teacher creativity, innovativeness hard work. This is because teachers would have to search the web for relevant material which they would customize for use in class to meet learner's individual needs. The innovation also demands costly infrastructure to be in place, facilities, resources policy, professional support, secure storage and maintenance.

In order to appropriately integrate ICT for improved education quality both technology and pedagogy must be addressed in the aspect Koehler calls Technological pedagogic Content Knowledge (TPACK) [8]. Inappropriate use of technology in education can lead to negative effects and that should be avoided [11]

On the other hand effective use of ICTs as teaching learning resources has been associated with significant increase in students' achievement. Students gain confidence as they get engaged by their teachers and sometimes work together with teachers as co workers in attempt to solve some technological problems [4]. The students also get engaged in activities of searching the web, solving problems and conducting other class activities with aid of technology which they find exciting and complete their own learning tasks which they sent back to the teacher through email.

Effective use of ICTs as teaching learning resources has been found to significantly increase students' achievement [2]. Use of ICT integration also promotes students critical thinking and problem solving skills needed in life [15].

However many developing countries, Kenya included, have found use of ICT in education an uphill task despite the government's demonstrated willingness to support the venture [10].

News in a local daily that a little unknown public secondary school in Kenya had made efforts to integrate ICT in curriculum delivery helped the researcher to identify a case that would reveal teachers motivation to integrate ICT in curriculum delivery [7]. It raised the researcher's curiosity to establish the major influences of the schools 'efforts to make the reported achievements. The school had 
been at the bottom of academic ebb and without much recognition in the late 1990s.

Moreover the break though had come after research by Iveneo and Kidombo had reported that there was very little integration of ICT in curriculum delivery in many secondary schools in Kenya as it was in many other developing countries [6] [9].

The main aim of the study was to confirm whether the school was integrating ICT in education and also to establish the motivation of the ingenious undertaking.

This study therefore investigated teachers' computer literacy, the purpose for which computers were used by the teachers in the school, the factors that led to the reported success in the school's use of the computer as a teaching learning resource, the motivation for the teachers specifically use of computers and other ICTs as teaching learning resource and impact of use of computer in teaching on students' learning. The experience is useful in students' life in a technology enriched environment that is anticipated and has already been experienced.

\section{Literature Review}

Research by Kidombo, Gakuo and Kindachu had found out that integration of ICT in curriculum delivery in secondary schools in Kenya depended on schools' leadership, professional training of the teachers in ICT, school manager's level of ICT skills competence and presence of school ICT policy [9]. Private schools were found to have had ICT policy which the public schools lacked.

Kombo reported that despite the Kenya government's effort and willingness to promote ICT as an instructional tool, progress on ICT font had fallen short of expectation [10]. The report added that the Ministry of education strategic plan for 2008- 2012, slow integration of ICT in operations and programmes was identified as an area of major weakness in the part of the ministry.

Literature by Bryderup and Kowalsk also informed that the development of ICT school plan with clear goals and defined means to realize the goals was a crucial step towards actual ICT integration and a visionary leader was a major requirement as well [3]. A school culture was another variable considered critical in success of an innovation in a school. Above all, success in integration of ICT in curriculum implementation depends on the motivation of individual classroom teachers as expounded by Tonduer [18]. Teachers' atttitudes and beliefs were seen as the main factors influencing implementation of an innovation such as ICT integration in curriculum implementation. Teachers interpret innovations according to their personal beliefs [14]. They accept more easily innovations that are in accordance with their own personal perceptions of teaching and learning.
Further ICT integration in education was therefore unlikely to succeed unless teachers personal educational beliefs and their relationship to teaching were established and effectively addressed and refocused to support the ICT integration venture [13]. This also illustrates need for teacher training on ICT integration and sustained regular in service.

Researchers are in agreement that use of ICT in Education as instructional media does not only enhance learning outcomes but it is also crucial in preparation of the youth for challenges of globalization in the 21 st century [11] [13]. With ICT learners engage in higher order thinking which most likely would be transferred to their daily lives to address challenging issues; it provides learners opportunity to construct and process knowledge. Use of ICT therefore does not only impart knowledge and skills but also builds human capital which sets technological innovations and economic growth.

ICT integration at school level depends upon school shared goals and visionary leadership. These variables need to be addressed to achieve school improvement. There is therefore need for the school to develop ICT school plan and policy targeting shared goals and objectives to enhance school improvement programmes such as use of ICT in curriculum instruction.

\section{Theoretical Framework}

This study was guided by the school improvement approach articulated by Tonduer and Technological Pedagogical Content Knowledge (TPACK) framework [8] [18]. School improvement approach to educational change embodies the long term goal of establishing a self renewing school and stressed the central role at the school level to mediate change and focus on the problems and internal conditions of the school [18]. At the school level there should be clear goals and systematic strategies to direct educational innovations. In addition there should be team development and professionalism of principals and teachers. Strong leadership at school level is critical for an innovation to take root and to guide change efforts [18].

Teachers play a central role in school improvement. Teachers' experiences beliefs, emotions, knowledge, skills, motivation are critical in school improvement. Teacher's perception and actions towards changing and developing their teaching methods are influenced by what they believe as well as their knowledge. Therefore prioritizing teacher education and teacher professional development are critical in an innovation such as ICT integration targeting improved classroom instruction and education quality. 
The variables: teacher motivation, visionary leadership and school level effort were critical in this study.

In the TPACK framework, it is argued that effective technology integration for teaching specific subject matter requires understanding and skill to negotiate the relationships between Technology, Pedagogy, and Content [8]. A teacher who is able to negotiate the relationships represents a form of expertise different and broader than the knowledge of an expert in a discipline. In the PACK framework there exists a complex relationship between content, pedagogy and technological knowledge areas that form a useful organizational structure for defining what it is that teachers need to know to integrate technology effectively. Teachers require knowledge and skill to use technology, subject content knowledge and pedagogic knowledge for ICT integration in education.

Technological knowledge, content knowledge and pedagogic knowledge were other critical variables in this study.

\section{Methodology}

The study adopted case study where one case that had the required information was identified to investigate the motivation for teachers to embrace use of ICT in education among others and a Secondary school was found to be appropriate because qualification of most secondary school teachers in Kenya is a university degree hence well educated to grasps and navigate technological fields. The school was studied in details. The secondary school was a boys boarding school near Ngong town, Kajiado county in Kenya. There were 535 students and 28 teachers. Simple random sampling was used to sample 30 students and 18 teachers who participated in the study. The teachers filled in a questionnaire and the students were observed conducting their class activities using computers.

\section{Findings and Discussion}

The study findings were presented based on investigation on: the subjects taught by teachers who participated in the study, teacher computer literacy, purpose for which computers were used by teachers, impact of use of computers on students' learning and teachers' perception of the reasons for success in ICT integration.

The following were the subjects taught by the teachers who participated in the study: Business studies, Kiswahili, History, Geography, Mathematics, Religious Education, Computer Studies, Physics and Chemistry. However data were not collected on performance of the individual subjects the teacher participants taught. Rather schools' improved performance was based on report given on the schools' aggregate performance in the Kenya Certificate of Secondary Education Examination (KCPE).

\section{Teachers' Computer Literacy}

All the teachers reported that they were computer literate. It was also observed that the teachers used computers to teach. The finding was in agreement with the information the researcher had gathered from one of the teachers in the preliminary discussion. The teacher had explained that all teachers and students were computer literate and the findings served for triangulation. The teacher had explained to the researcher how teachers acquired computer literacy and the explanation was captured verbatim as follows:

Any new teacher who joins this school joins evening computer literacy classes and after about two months the teacher acquires basic computer literacy skills. The teacher then trains students on how to use the computer and the students teach one another after classes how to work with computer in the computer lab with supervision of the teacher on duty. Teachers post students assignments in the school website. Teachers also learn from one another how to gather material from the web and customize it for use in their class lessons. They then locate relevant content from the internet, edit and customize the content for use in the lesson they are to teach. It is also easy to explain concepts when cast on screen, and no teacher wants to be left behind. Students understand better when presented with real pictures, let's say of digestive system in biology or a historical figure in history. You know the computer makes work easy and enjoyable so those of us who have higher computer skills and is more innovative and creative in the area help others.

The teachers' computer literacy status gave them confidence to try new pedagogies supported by technology. Teacher confidence had been cited as a drawback in ICT integration which the studied school had succeeded in overcoming through innovative ingenious approaches [1]. However the teachers require training and sustained professional development in ICT integration in instruction.

\section{Purpose of Use of Computer by teachers}

The teachers were required to state the purpose of their use of computer and the responses were as on Table 1. 
Table 1. Use of Computer

\begin{tabular}{llc}
\hline Uses & f & \% \\
Research, teach, plan, & & \\
keep records & 14 & 77.7 \\
Teach only & 00 & 00.0 \\
Research only & 01 & 05.6 \\
Keep record only & 02 & 11.1 \\
Plan only & 01 & 05.6 \\
Total & 18 & 100.0 \\
\hline
\end{tabular}

Table 1 indicates that the majority of the teachers $14(77.7 \%)$ used the computer to research, teach, plan and keep records. It is clear that the computer was used by the vast majority of the teachers in the school for instruction. This provided students opportunity to interact with modern technology. Institutions that do not incorporate the use of new technology in school cannot seriously claim to prepare learners for life in the 21st century which operates like a global village. Technologies play a role in students' skill development, motivation and knowledge construction and processing.

Use of computers enables students to acquire knowledgeable; teachers reduce transmission and allow for knowledge construction and processing by students required for the 21st century knowledge economy. New technologies can help teachers to enhance their pedagogical practice and enhance students learning.

\section{Teacher Motivation for Use of the Computer for instruction}

The teachers were required to indicate the motivation for their own use of computer for instruction and their responses are presented on Table 2

Table 2. Motivation for Computer Use

\begin{tabular}{lll}
\hline Motivation & f & \% \\
Desire to teach better & 15 & 83 \\
School requirement & 03 & 17 \\
All others used it & 00 & 00 \\
Outside pressure & 00 & 00 \\
Total & 18 & 100 \\
\hline
\end{tabular}

From Table 2 the greatest drive for the teachers to use ICT in instruction was the teachers desire to teach students better reported by the vast majority $15(83 \%)$ of the teachers. Such a positive attitude raises teacher and learner enthusiasm. Feldman pointed out that teacher enthusiasm has power to influence students' cognitive, affective and motivational outcomes with its intrinsic motivation [20]. Teachers' desire to teach better was the right drive. Stoll also argued that teachers play a central role in school improvement and in bringing about the success of an innovation [15]. The study therefore established that there was teachers' strong self drive. Kidombo, Gakuo and Kidacho emphasized motivation for ICT integration in instruction at school level [9]. Further illustration of teachers' self drive was demonstrated by the following data gathered verbatim from teachers from one teacher participant:

We join self help 'merry go round groups', make contributions and buy our own lap tops. That way we were able to buy for ourselves lap tops and other technological accessories that made ICT resources accessible to us.

Each teacher in the school had a lap top which they had made private arrangements and purchased for themselves as illustrated and that catered for the challenge of resources that hinder ICT integration.

\section{Impact of Use of Computer in Learning}

Teachers were also asked to indicate the impact of their use of ICT in students learning. Table 3 presents the findings.

Table 3. Impact of use of Computer on Students' Learning

\begin{tabular}{|c|c|c|}
\hline \\
\hline The Impact & f & $\%$ \\
\hline $\begin{array}{l}\text { Raised the student's enthusiasm, interest } \\
\text { and creativity }\end{array}$ & 10 & 56 \\
\hline Student Became Bored & 00 & 00 \\
\hline Improved students performance & 08 & 44 \\
\hline Total & 18 & 100 \\
\hline
\end{tabular}

Table 3 indicates that the majority10 (56) of the teachers reported that teaching using computer as a tool raised students enthusiasm, interest and creativity. This was triangulated with the researcher's findings where 30 students were observed using computers during their own time engaged in working on their assignment and their own study and performed their own academic activities with the supervision of the teacher on duty and both the observation and self report were in 
agreement. Learner enthusiasm enhances learning environment and plays a key role in learning [16].

Research reports indicate that it is not possible to obtain empirical evidence of use of ICT impact on learning [12]. However ICT use in teaching has effect on several teaching approaches such as collaborative learning and activity learning which have been associated with positive impact on learning outcome.

\section{Teachers' Perceptions of Reasons for Success in ICT Integration}

The teachers were to indicate their perception of reasons for the schools' success in use of ICT in teaching and Table 4 presents the findings.

\begin{tabular}{lll}
\hline Reason & $\mathbf{f}$ & $\mathbf{\%}$ \\
Teacher desire to work better & 09 & 51 \\
Support from head teacher & 06 & 33 \\
Support from parents & 00 & 00 \\
Support from Government & 03 & 16 \\
Total & $\mathbf{1 8}$ & $\mathbf{1 0 0}$ \\
\hline
\end{tabular}

Table 4 shows that the teacher desire to work better was the greatest contributor to the success of the ICT integration in instruction. There was also substantial support from the school principal $06(33 \%)$ and some support from the government. This was in agreement with report which indicated that the school had made effort to solve their own ICT issues [7]. The school had its own ICT policy, support from the school principal, the school alumni and the teachers were self motivated to teach better. The school principal was reported to be very supportive and had provided the teachers a relaxed friendly learning environment. The schools' staffroom provided comfort and teachers would relax there during break time. Brain research supports friendly learning environment. It has indicated that learning takes place in the neocotex which does not function well under stress or fear [17].Therefore a learning environment should be attractive, friendly and stress free. This could heavily be attributed to good leadership. It was argued that there was need for good leadership and a friendly atmosphere in success of implementation of an innovation [9].

All the 30 students observed by the researcher concentrated on their own work using computers independently. The report from the school's performance in Kenya Certificate of Secondary Education indicated that the school's mean score improved from 6.2 to 8.4 between 2007 and 2013 [7].

The study was therefore effectively guided by the school improvement approach and by TPACK framework because school level professional development was central in the study and emphasis was all through laid on technological knowledge, content knowledge and pedagogic knowledge which tend to be intertwined.

\section{Conclusion}

It came out clear that the studied school was integrating ICT in instruction which benefited both teachers and learners. The greatest motivation for integration of ICT in education was found to be the teachers' desire to teach better. School supportive leadership played a second leading role.

\section{Recommendations}

It was recommended that schools need to integrate ICT in education which is the way so far viable to prepare learners to operate in the modern knowledge economy which is expected to further advance in future. Schools should play a leading role to implement ICT at the school with self help initiative. Teachers should show initiative and the school leadership should support and create an enabling teaching learning environment for teachers and students.

The philosophy of pulling resources together and self help could be applied and further source support from alumni and other well wishers to facilitate ICT integration in education at school level. The government should support schools more by ensuring that they access electricity and internet connectivity. The parents and the community should also be supportive. There is a lot other schools could emulate from the studied secondary school. Future study should investigate specifically impact of ICT integration in students, performance of the subjects the teacher participants study, teach and means of incorporating parents and local community to support ICT integration in instruction.

\section{References}

[1] Abdullah, K. (2009). Barrier to Successful Integration of ICT in Teaching and Learning Environment. A review of Literature. University of Bandoora Vic Australia. Eurasia Journal of Mathematics Science and Technology 5(3) 235-245

[2] Bitner, N. and Bitner, J. (2002). Integrating technology in the classroom. Eight Keys to Success. Journal of Technology and Teacher Development. 
[3] Bryderup, I.M. \& Kowalsk, K. (2002). . The Role of Local Authorities in the Integration of ICT in Learning, Journal of Computer Assisted Learning 18,470-479

[4] Grabe, M\& Grabe, C. (2007). Integrating Technology for Meaningful Learning. 5th Ed. Boston NY. Houghton Mifflin

[5] Gray, P. J. (2007). Viewing ssessment as an Innovation: Leadership and the Change Process. New Directions for Higher Education, 25,5-15

[6] Iveneo. (2011). ICT Works. 12 Challenges Facing Computer Education in Kenya. Guest Writers

[7] Kariuki, N.(2014). A Peek into Kenya's Education Special Report. ICT takes Oloolaiser School to the Next Level. Spring Board.The Daily Nation Monday, March 1st P.1

[8] Koehler, M. (2011).Pedagogical Content Knowledge Posted in Core 13th May 2011

http://mkoehler.educ.msu.edu/tpack/cate gory/core/

[9] Kidombo, Gakuo \& Kindachu. (2011). Closing the Chasm: Are the Secondary School Teachers in Kenya Using ICT Effectively to Deliver Curriculum Content? University of Nairobi School of Continuing and Distance Education

[10] Kombo, N. (2013). Enhancing Kenyan Students Llearning Through ICT Tools for Teachers. Centre for Educational Innovation. An Initiative for Results for Development Institute

[11] Lim, C.P. (2002). A Thoretical Framework for the Study of ICTs in Schools: A Proposal. British Journal of Educational Technology, 4, 411-421

[12] Liisa, I. (2008). The Effect ICT on school: teacher and students perspective.

Turku. Finland

[13] Mbodila, M. \& Kikunga, M. (2012). The Use of ICT in Education. A Comparizon of Traditional Pedagogy and Emerging Pedaogy Enabled by ICTs. Proceedings of the 11th International Conference on Fontier in Education

[14] Pajares, M. F., (1992). Teacher Beliefs and Educational Research: Cleaning Up a Messy Construct. Review of Educational Research, 02, 307-332

[15] So, J.H. \& Kim, B. (2009). Learning About Problem Based Learning. Student- teacher Integrating Technology and Content Knowledge. The Australian Journal of Research

[16] Scheerens, J. (2008). System Level Indicators Paper for INES Network c. Enschede: University of Twente Educational Technology. 25(1), 101-116

[17] Sparrow \& Frid (2006). Beginning Teachers of Primary Mathematics.

Recurring Themes and Emerging Issues. Curtin University of Technology www.aare.edu.au/o/pap/image241.gf
[18] Tonduer, J. (2007). Development and Validation of Model of ICT Integration in Primary Education. Univesitiet Gent

[19] Williams, M. D. (2003). Technology integration in education. In Tan, S.C. \& Wong, F.L. (Eds.), Teaching and Learning with Technology, pp. 17-31: An Asia-pacific perspective. Singapore:

Prentice Hall

[20] Feldman, K. A. (2007). Identifying Exemplary Teachers and Teaching: Evidence from Student Ratings. The scholarship of teaching and learning in higher education - An evidence-based perspective ( $p p$. 93-143). Dordrecht: Springer. 